\title{
Histone Modification
}

National Cancer Institute

\section{Source}

National Cancer Institute. Histone Modification. NCI Thesaurus. Code C129422.

Post-translational processing of amino acids within a histone protein. 